INTERDISCIPLINARIA ARCHAEOLOGICA NATURAL SCIENCES IN ARCHAEOLOGY

\title{
X-Ray Fluorescence Analysis of the Pottery Shards from Dahan-e Ghulaman, the Achaemenid Site in Sistan, East of Iran
}

\author{
Hossein Sarhaddi-Dadian, ${ }^{\mathrm{a}, \mathrm{b}^{*}}$, Hossein Moradic, Zuliskandar Ramlid, Vahid Purzarghan ${ }^{\mathrm{b}}$ \\ ${ }^{a}$ Department of Archaeology, Faculty of Art and Architecture, University of Zabol, 98615-538, Bonjar Ave, Zabol City, Iran \\ ${ }^{b}$ Archaeological Research Centre, Faculty of Art and Architecture University of Zabol, 98615-538, Bonjar Ave, Zabol City, Iran \\ 'Iranian Centre for Archaeological Research, Tir Street 30, Imam Khomeini Avenue, Tehran, Iran \\ ${ }^{d}$ Institute of the Malay World and Civilization, The National University of Malaysia, 43600 Bangi, Selangor, Malaysia
}

\section{ARTICLE INFO}

\section{Article history:}

Received: $21^{\text {st }}$ September 2016

Accepted: $31^{\text {st }}$ May 2017

DOI: http://dx.doi.org/ 10.24916/iansa.2017.1.3

Key words:

archaeometry

pottery

X-Ray Fluorescence (XRF)

Achaemenid

Dahan-e Ghulaman

\begin{abstract}
$A B S T R A C T$
The aim of this study was to determine whether pottery shards from Dahan-e Ghulaman were locally made or imported from elsewhere. Dahan-e Ghulaman is one of the most ancient settlements in Iran's Sistan during the Achaemenid period. The study shows that the antiquity of the site goes back to the $6^{\text {th }}$ and $5^{\text {th }}$ centuries BC, the earthenware found in Dahan-e Ghulaman being simple and unpainted in buff and buffish red colours. However, another type of pottery also can be observed in the Dahan-e Ghulaman collection; these are painted red inside and milky outside, and are similar to ceramics from the Nadali site in Afghanistan. The dishes include short cups with wide mouths in red and orange. Archaeologists believe that most of the pottery shards are locally made; hence, to test this hypothesis, a scientific analysis was done to determine the chemical composition of the pottery shards. X-Rays Fluorescence (XRF) was applied to determine the major and trace elements of the pottery shards. The results demonstrate that most of the pottery shards are in the same group and this strongly suggests that they are local products. Additionally, based on the major and trace elements, it can be suggested that five samples are not locally made.
\end{abstract}

\section{Introduction}

Sistan is located in a vast territory in the south-east of Iran, and a large part of it today is in Afghanistan. The Sistan region, along with Baluchestan, constitutes the Sistan and Baluchestan Province of Iran (see Moradi et al. 2013; 2014; Sarhaddi-Dadian 2015a; 2015b). Although the land has had a major role in the development and spread of Iranian Civilization and culture (Sheikhakbari et al. 2015), the material culture of Sistan was not introduced to other parts of Iran. Sistan with its subtropical climate is one of the arid regions of Asia. This area's climate is different from the surrounding areas with their steppe climate, wet winters and dry summers. In Sistan, annual rainfall is very low and between September and May this amount is only about $50 \mathrm{~mm}$, with the rest of the year dry with no rain. Since the volume of annual rainfall in Sistan is less than $300 \mathrm{~mm}$, the land is potentially unsuitable for cultivation.

*Corresponding author. E-mail: h.sarhaddi@uoz.ac.ir
The warmest months of the year are July and August, with an average temperature of $32^{\circ} \mathrm{C}$, and the coldest is January with an average temperature of $5 / 7^{\circ} \mathrm{C}$. However, with adequate quantities of water, the land can be cultivated. Important natural phenomena in this region are rivers and lakes, each having had an important role in the narrative history and development of civilization in the Sistan district (SarhaddiDadian 2013). During the Achaemenid Empire, this region was one of the most significant areas of ancient Iran. The name of this state, in the inscription of Achaemenid's King Darush, is Zarankeh, (Sharpe 2004) and Drangiana in Greek classical historian reports. Alexander the Great spent some time in Drangiana on his way to conquer India. According to the Greek geographers and historians, the location of Alexander the Great was to the north of Sistan, which was called Proftazia. This location has been mentioned in Sistan historical books. Reaching for power by the Greek Army, they took Sistan and established the Western Greek Government. Apparently Sistan was the most important province, for the crown prince ruled as lieutenant governor in Drangiana. The Greeks created many cities in Sistan. Ptolemaios, the famous 
Greek writer, has mentioned the eleven largest and most famous cities in Drangiana (Mehrafarin 2016). Considering the archaeological evidence, most of the archaeologists believe that the site of Dahan-e Ghulaman had been the capital of Sistan during the Achaemenid period.

\section{Dahan-e Ghulaman site}

Dahan-e Ghulaman is located about $44 \mathrm{~km}$ from Zabol city and $2 \mathrm{~km}$ from the Kale New Village in the north of the province of Sistan and Baluchestan, Iran (Figure 1). This site was discovered and excavated by Umberto Scerrato in 1960-1965 (Scerrato 1966). After the Iranian revolution, in October 2000, Seyyed Mansour Seyyed Sajjadi began a new series of excavations in Dahan-e Ghulaman (Sajjadi 2007). The reports and maps from the Dahan-e Ghulaman site prepared by the Italian demonstrate that the site was covered by dunes located alongside the Hirmand River among several historical sites (Mariani 1977; Sceratto 1962).

The buildings are arranged in fairly regular rows, and due to the 120-day wind phenomenon which always blows from northwest to the southeast, all of the entrance doors are located on the southern side of the building or wind breakers have been built in front of them. The main walls of buildings have been constructed using strong bricks. The rooms' roofs are crescent dome-shaped and they are located next to each other forming a beautiful architecture (Mariani 1977).

The buildings are distributed over an area $200 \mathrm{~m}$ in length, from $300 \mathrm{~m}$ to $800 \mathrm{~m}$ in width and about $300 \mathrm{~m}$ from the dried Senate River Delta. Only worn and broken pottery

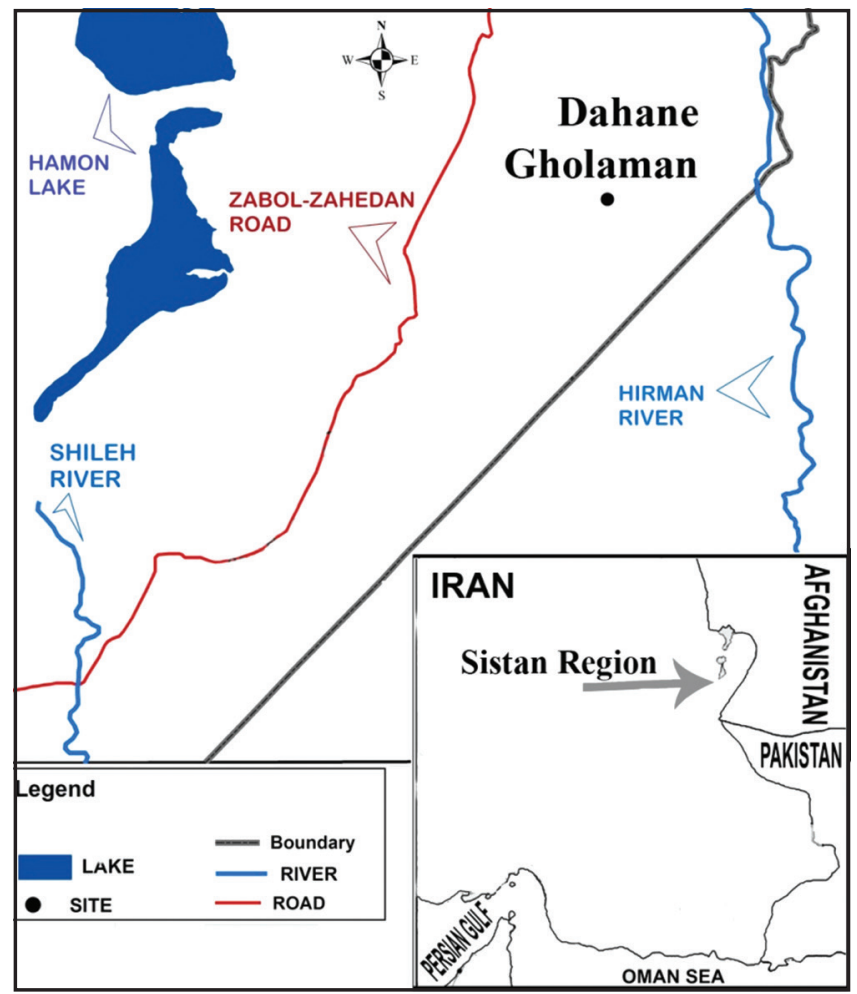

Figure 1. The location of the Dahan-e Ghulaman site in the Sistan Region. shards have been found scattered across the city. Owing to its size and extent of the buildings in the city, it is clear that the main city had been larger (Genito 1990). This city had a short life of between 150 to 200 years in the $6^{\text {th }}$ and $5^{\text {th }}$ centuries BC. The city had been built with a remarkable plan and for a specific purpose, making it a good example for the study of trends in urban history (Cattenat, Gardin 1977).

Dahan-e Ghulaman had been shrinking slowly and the evidence shows that no significant artefact has been found in the excavation. The city had been evacuated voluntarily and not due to external factors such as war or fire. After that, Dahan-e Ghulaman had been used seasonally by nomads and shepherds. Flowing sand gradually covered all the buildings for more than 2000 years (see Later, Genito 2010; Sajjadi 2006).

\section{Material and methods}

\subsection{Dahan-e Ghulaman's Potteries}

According to the morphology and typology, Dahan-e Ghulaman's pottery does not show many variations. A chronological analysis of the pottery by Genito has shown that the antiquity of the site goes back to the $6^{\text {th }}$ and $5^{\text {th }}$ centuries BC. (Genito 1990). In total, the earthenware of Dahan-e Ghulaman is simple and non-painted in buff and buffish red colours, but another type of pottery can be seen among the Dahan-e Ghulaman collection. These have a red colour inside and a milky colour outside and look like the pottery of the Nadali site in Afghanistan (Dales 1977). The dishes include short cups with open mouths in red and orange colours. Some of them have the potters' signs. A group of them have been detected from room No. 1 in building No. 15 beside the large pottery oven, and other different fragments can be seen in rooms No. 2 and 3. Besides the cups, different types of pottery, including deep bowls and vats, can be observed. The pottery objects in building No. 15 can be divided into four groups:

1. A large part of building No. 15 had been made from cylindrical pipes, and these were filled at the bottom with rough bodies in buff and orange, and found in rooms No. 1, 2 and 3 . The cylindrical pipes filled at the bottom are placed at a distance of 20-25 cm from each other in room No. 1, while the cylindrical pipes in room No. 2 can be observed as irregular, scattered, and broken, along with scarred and unscarred hand stones. The lengths of the pipes are almost identical-between 23 and $30 \mathrm{~cm}$. It does not seem that these differences had a significant impact on the use the pottery tubes were put to. The edge shape and holes created in the pipes are not in a standard form, and they are different from each other. The whole diameter decreases gradually from the top to the bottom, and the indication is that they have been created by a great twist. Apparently they have similar shapes, but with different rim shapes, which have been divided into the following five types: 1. Pipes with an everted globular rim, 2. Deep pipes with flat edges, 3. Pipes with fully-drawn everted rims, 4. Pipes with angled edges, which are convex, 
5. Pipes with a cylindrical body, and inverted rims (Sajjadi 2002).

2. Large dishes: these pieces of pottery have been obtained from building No. 2. However, we are unable to reconstruct them as they are damaged. This pottery can be classified in terms of the building techniques employed, such as: 1. Red rough pottery mixed with oil materials that include small and large dishes, 2. Common pottery, including red, orange, and buff colours with a clear cover, which had been locallyproduced in Dahan-e Ghulaman. The shapes were mostly scaphoid cups, vats with flat bases, ventricular vats with trumpet-shaped bases - but these are very few in number, a kind of cylindrical pot, and large pots with a trumpet base. Though there were few types of decoration on the pottery, they included straight lines, wavy lines, and stylized motifs (Scerrato 1966b).

3. Monochrome pottery with sieved soil and different colours: the pottery shards are in red, pink, brown and yellowish colours; the dishes have thin bodies and include oblique bodies, scaphoid, stemless cups, and large containers. All of the pottery shards were simple except for one that had a geometrical vine shoot (Scerrato 1962).

4. Polished bicolor pottery: these pieces usually have red colours inside and a white colour outside, and a rather thick glaze (Scerrato 1966b).

According to Genito who studied them, the pottery of Dahan-e Ghulaman can be divided into two major groups as follow: A. Unrestricted dishes, and B. Restricted ones.

\subsubsection{Unrestricted dishes}

1. Cylindrical-conical beakers: These pottery pieces are medium-sized and their heights are greater than their width. The cross-sectional profile shows a small concave body and a vertical height with sharp edges. They are in some ways similar to the cylindrical containers that had spread out from the traditional period, the Iron Age in the northeast of Iran (Cattenat, Gardin 1977). There can be two different typologies common between the northeast of Iran and Sistan. The former is $17.30 \mathrm{~cm}$ high and the latter is $10.15 \mathrm{~cm}$. The base of the first type is usually an inverted cone that is separated with great variation in the body (Genito 1990). The vessel type of the Iron Age can have certain forms in northeastern Iran, with pear-shaped biconical beakers at Shahre Sokhta (see Buson, Vidale 1983; Tosi 1969). The containers of Dahan-e Ghulaman have two features, related to the production of the kick wheel, which include concentric lines and symmetrical signs on the outer surface of the base. The spiral is created by moving the kick wheel at the bottom level of their insides (Genito 1990), and is comparable to the pottery shards of Pasargad site in terms of edge form and container shape (Stronach 1978).

2. Carinated Cups: The most distinctive morphological features of these cups are steep slopes that have been located at $2 / 3$ the height of the containers. The name "Carinated Cups" was suggested by Sceratto (Sceratto 1962), while other researchers have used different expressions, such as assiettes carenees a levre horizontal (Cattenat, Gardin 1977), or shallow bowls with a prominent horizontal rim (Vogelsong 1987). These cups or bowls were widely distributed in Iranian territories from the Iron Age until the $3^{\text {rd }}$ or $4^{\text {th }}$ centuries BC. This type of pottery also has been detected from Arachosia and northwest Iran, but these are different from the shapes at Dahan-e Ghulaman, and have still not been found on this site. Carinated cups have been scattered in various geographic areas. They have been observed from the northwest of Iran to Afghanistan. The carinated cups of Sistan can be observed from Sorkhe Dagh, the Babajan Site, Pasargad, Persepolis, and Yahya Tape.

3. Truncated Conical Cups: These are very small items with an everted edge and are flat; generally they are from good material in a cream colour. They have very special shapes, slightly similar to carinated cups, but without the steep slope (Genito 1990).

4. Dishes: They are low and shallow. One of them has a height of $5 \mathrm{~cm}$ and a rim diameter of $20 \mathrm{~cm}$. They are unpainted produced wares in red and cream colours, seemingly of local production, but there have been similarities found in Afghanistan, central Asia, and northwest Iran.

5. Basins: The basins are large-sized containers with a height of $45 \mathrm{~cm}$ and diameter of $70 \mathrm{~cm}$. Their main features include a moulded rim, horn-shaped base, oblique-sided body and they are analogous with the pottery of Kalamary and Bactria. Other shapes selected from this site are spherical, globular bowls, which are divided into two types: large and small. The small one is closed, similar to the Sorkhe Dagh site, while the large items are comparable with the Dur-khan site in Pakistan (Genito 1990).

\subsubsection{Restricted Vessels}

Three types of this pottery have been discovered on this site. The first type has a very large size: $70 \mathrm{~cm}$ in height, $71 \mathrm{~cm}$ in diameter, a rim diameter of $36 \mathrm{~cm}$, and horn-shaped base of $19 \mathrm{~cm}$. A similar type has been found at different sites, such as: Giyan and Siyalk in northwestern Iran; Anau, and Namazga VI in northeastern Iran; in Margiana at Jaz Tape III, Ancy, and Taxirbai, Dashli 1 and 3 in Bactria, and Nadali in Afghanistan. The second type includes a cylindrical body, a big mouth and horn-shaped base, with a $60 \mathrm{~cm}$ height and $29 \mathrm{~cm}$ rim diameter. The pottery has its most common relationship with the examples of the Kjuzeli Gry and Dasli 1 and 3 sites. The third type has a flat bottom that is oval-shaped with a different kind of edge and neck, though with very few examples present (Ibid, Plate Nos. 96-98).

\subsection{Sample Preparation}

For the analysis, in order to determine the chemical composition of the pottery, each sample of weight $0.7 \mathrm{~g}$ was pulverized, heated up at a temperature of $105^{\circ} \mathrm{C}$ for one hour and mixed until homogenous with the flux powder, a type of Spectroflux 110 (product of Johnson \& Mathey). These mixtures were baked for one hour in a furnace with a temperature of $1100^{\circ} \mathrm{C}$. The homogenous molten material was moulded in a container and cooled gradually into pieces of fused glass with a thickness of $2 \mathrm{~mm}$ and a 
diameter of $32 \mathrm{~mm}$. The samples were of 1:10 dilution. Press pallet samples were prepared by mixing $1.0 \mathrm{~g}$ of samples together with $6.0 \mathrm{~g}$ of boric acid powder; then, a pressure of 20 psi (137.895 kPa) was applied using hydraulic pressure equipment. The samples of fused pallets and pressed pallets were analyzed by wavelength-dispersive X-Ray Fluorescence (WD-XRF). A Philips PW1480 sequential spectrometer fitted with a rhodium-anode X-Ray tube $(3 \mathrm{~kW}$ $60 \mathrm{kV}$ ) was used for the analysis of major and trace elements. The spectrometers were controlled using Philips X40 application software package version 3.2 and 4.01 running under the DEC VMS operating system.

Scatter plot diagrams of $\mathrm{SiO}_{2}$ versus $\mathrm{CaO}$, and $\mathrm{CaO}$ versus $\mathrm{MgO}$, were then performed to demonstrate the differences among the groups and was analyzed using Microsoft Excel software. The main purpose was to see the distribution of the samples in the group. Hierarchical Cluster Analysis (HCA) was applied to the chemical data from the three components, namely silica $\left(\mathrm{SiO}_{2}\right)$, calcium $(\mathrm{CaO})$ and magnesium $(\mathrm{MgO})$. All the 15 pottery shards were sampled in order to verify the presence of compositional groups of pottery shards differentiated by their probable major element sources. The measurement of distance used in the assignment rule was based on Ward's Linkage and the Squared Euclidean Distance algorithm. The results are presented in the form of a dendrogram (Figures 5 and 6), showing in graphical form the distance between the pottery samples on the basis of their $\mathrm{SiO}_{2}$ and $\mathrm{CaO}$, and $\mathrm{CaO}$ and $\mathrm{MgO}$ percentages. The applicability of the analytical methods for the multi-elemental analysis of the pottery shards by XRF was evaluated using an analysis of certified reference material, 315 Fire Brick (Calibration: G_FBVac28mm) for major elements.

\section{Results and Discussion}

\subsection{XRF}

The X-ray fluorescence analysis of the 15 pottery shards samples was conducted to determine the major elements content in the pottery shards from Dahan-e Ghulaman (Figure 2). In the compositional analysis, each compositional group was taken to represent locally manufactured pottery based on the assumptions of the Provenance Postulate and the Criterion of Abundance. The Provenance Postulate assumes that compositional differences among different sources are greater than differences within a single source, and that these differences can be recognized by the analytical or compositional approach (Weigand et al. 1977). The Criterion of Abundance, on the other hand, holds that a ceramic unit (in this case, elemental abundance) strongly represented at a site, can be presumed to be a local manufacturer, while those scarcely represented are non-local (Bishop et al. 1982). The pottery samples show a quite homogeneous composition except for three samples, namely QH6, QH8 and QH26, that show high calcium content. The analysis also showed that samples QH8 and QH7 did not have any major sodium content. Additionally, half of the samples did not have any major sulphur content (see Table 1).

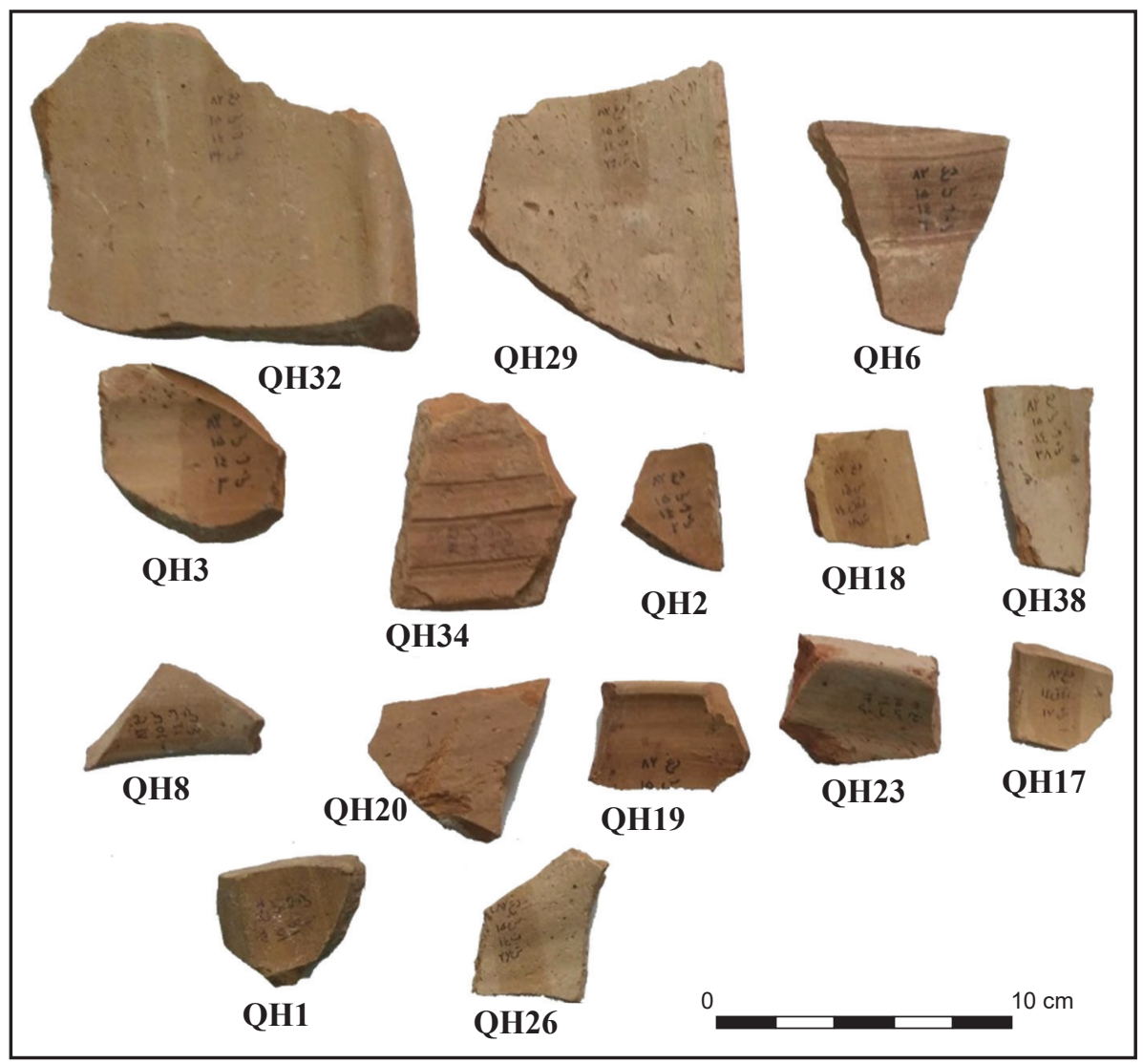

Figure 2. Potshards discovered from the site. 
Table 1. Major elements of pottery shards from Dahan-e Ghulaman.

\begin{tabular}{|c|c|c|c|c|c|c|c|c|c|c|c|c|}
\hline \multirow{2}{*}{ Sample } & \multicolumn{12}{|c|}{ Major elements (\%) } \\
\hline & $\mathrm{Na}_{2} \mathrm{O}$ & MgO & $\mathrm{A1}_{2} \mathrm{O}_{3}$ & $\mathrm{SiO}_{2}$ & $\mathrm{P}_{2} \mathrm{O}_{5}$ & $\mathrm{SO}_{3}$ & $\mathbf{K}_{2} \mathbf{O}$ & $\mathrm{CaO}$ & $\mathrm{TiO}_{2}$ & MnO & $\mathrm{Fe}_{2} \mathrm{O}_{3}$ & $\mathrm{SrO}$ \\
\hline QH1 & 1.7 & 3.8 & 15.3 & 64.5 & 1.2 & 0.670 & 1.2 & 5.6 & 0.38 & 0.650 & 5.4 & 0.079 \\
\hline QH2 & 1.1 & 4.6 & 15.1 & 60.4 & 2.1 & 0.580 & 1.7 & 5.8 & 0.49 & 0.086 & 7.9 & 0.073 \\
\hline QH3 & 0.98 & 4.4 & 13.2 & 63.5 & 1.6 & 0.370 & 1.6 & 5.9 & 0.50 & 0.078 & 7.8 & 0.068 \\
\hline QH6 & 1.4 & 4.2 & 14.3 & 61.7 & 1.0 & - & 1.1 & 7.3 & 0.53 & 0.087 & 8.2 & 0.052 \\
\hline QH8 & - & 4.3 & 13.4 & 62.0 & 1.2 & - & 1.5 & 7.2 & 0.58 & 0.094 & 9.5 & 0.080 \\
\hline QH17 & - & 4.1 & 13.9 & 62.4 & 2.2 & - & 1.6 & 5.9 & 0.63 & 0.075 & 8.8 & 0.075 \\
\hline QH18 & 1.2 & 4.7 & 14.2 & 60.4 & 1.7 & - & 1.5 & 5.6 & 0.60 & 0.098 & 9.8 & 0.061 \\
\hline QH19 & 2.4 & 4.9 & 12.9 & 66.6 & 0.84 & - & 1.4 & 4.5 & 0.37 & 0.058 & 5.8 & 0.071 \\
\hline QH20 & 3.1 & 4.6 & 10.8 & 65.4 & 1.9 & 0.034 & 1.7 & 4.8 & 0.54 & 0.060 & 6.7 & 0.13 \\
\hline QH23 & 1.4 & 4.6 & 15.9 & 62.1 & 0.77 & - & 1.5 & 4.7 & 0.50 & 0.077 & 8.3 & 0.072 \\
\hline QH26 & 1.7 & 6.6 & 13.8 & 60.1 & 0.93 & 0.026 & 1.3 & 7.7 & 0.46 & 0.077 & 7.2 & 0.058 \\
\hline QH29 & 2.8 & 6.3 & 14.3 & 57.2 & 1.7 & 0.520 & 1.5 & 5.5 & 0.58 & 0.091 & 9.3 & 0.073 \\
\hline QH32 & 2.8 & 5.3 & 17.6 & 57.3 & 1.3 & 0.490 & 1.5 & 4.6 & 0.50 & 0.079 & 8.3 & 0.081 \\
\hline QH34 & 2.3 & 5.1 & 15.7 & 54.9 & 5.5 & 0.620 & 1.8 & 5.6 & 0.47 & 0.091 & 7.8 & 0.095 \\
\hline QH38 & 2.2 & 6.3 & 15.5 & 56.8 & 1.4 & - & 1.6 & 5.7 & 0.56 & 0.120 & 9.3 & 0.68 \\
\hline
\end{tabular}

The range of silica dry weight is from 54.9 to $64.5 \%$. The content of aluminium is from $10.8 \%$ to $17.6 \%$. The content of iron and calcium are 5.4 to $9.9 \%$ and 4.5 to $7.7 \%$, respectively. Alkaline elements such as magnesium, sodium and potassium show their dry weight as 3.8 to $6.6,0.98$ to 3.1 and 1.1 to $1.8 \%$, respectively. The manganese and titanium contents are 0.058 to $0.65 \%$ and 0.37 to $0.65 \%$, respectively. The percentage of $\mathrm{P}_{2} \mathrm{O}_{5}$, which is high, shows that same of the samples have been used as containers for some organic materials. Analysis also shows that strontium has a dry weight percentage from 0.052 to $0.68 \%$. The analysis of Dahan-e Ghulaman pottery shards shows that none of the shards contained a very high percentage of dry weight of lead. Pottery made in India usually has a very high content of lead, which was added as a colouring agent (Caled 1991). Analysis on Shahr-I-Sokhta pottery shards showed that one of the pottery shards had a high content of lead (see Moradi et al. 2013; Sarhaddi-Dadian et al. 2015b).

\subsection{Scatter Plot and Cluster Analysis}

Figure 3 shows a scatter plot of $\mathrm{SiO}_{2}$ and $\mathrm{CaO}$ contents, and from the figure it is clear that most of the samples have similar concentrations of major elements, except for samples QH6, QH8 and QH26. Figure 4 shows a scatter plot of $\mathrm{CaO}$ and $\mathrm{MgO}$, the figure showing that most of the pottery shards have a very similar concentration of $\mathrm{CaO}$ and $\mathrm{MgO}$ content.
Figure 3. Scatter plot of $\mathrm{SiO} 2$ versus $\mathrm{CaO}$ percentage of pottery shards from Dahan-e Ghulaman.

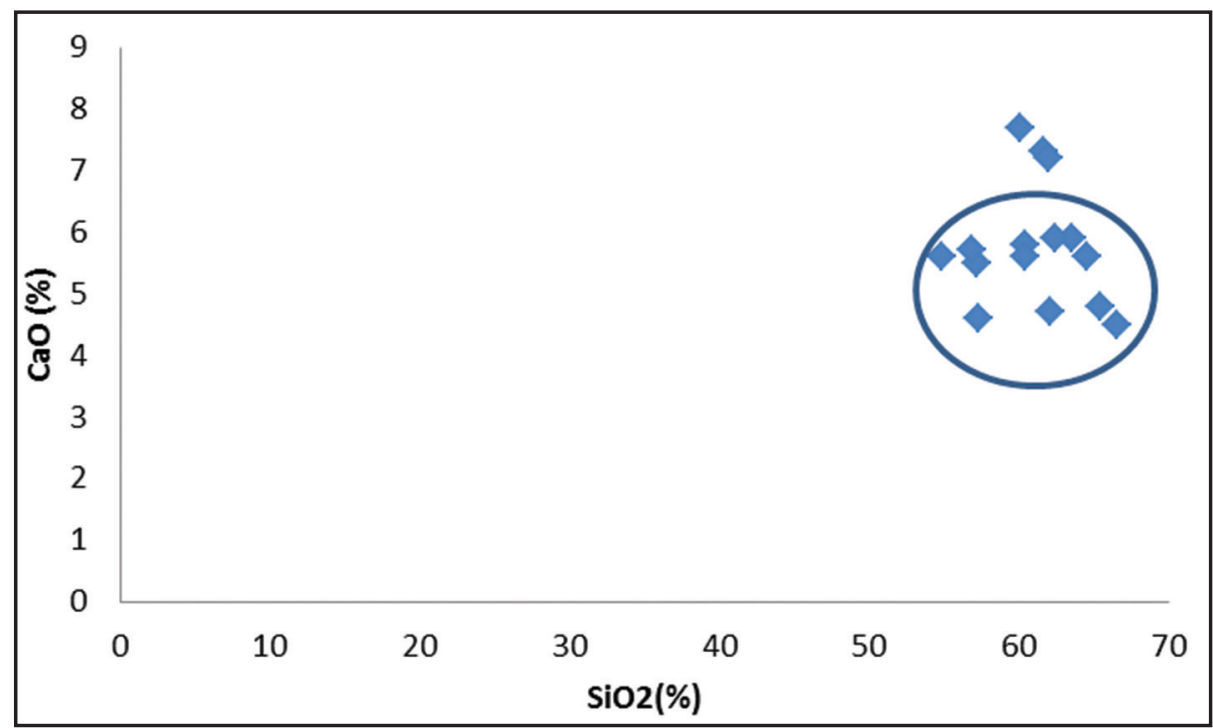




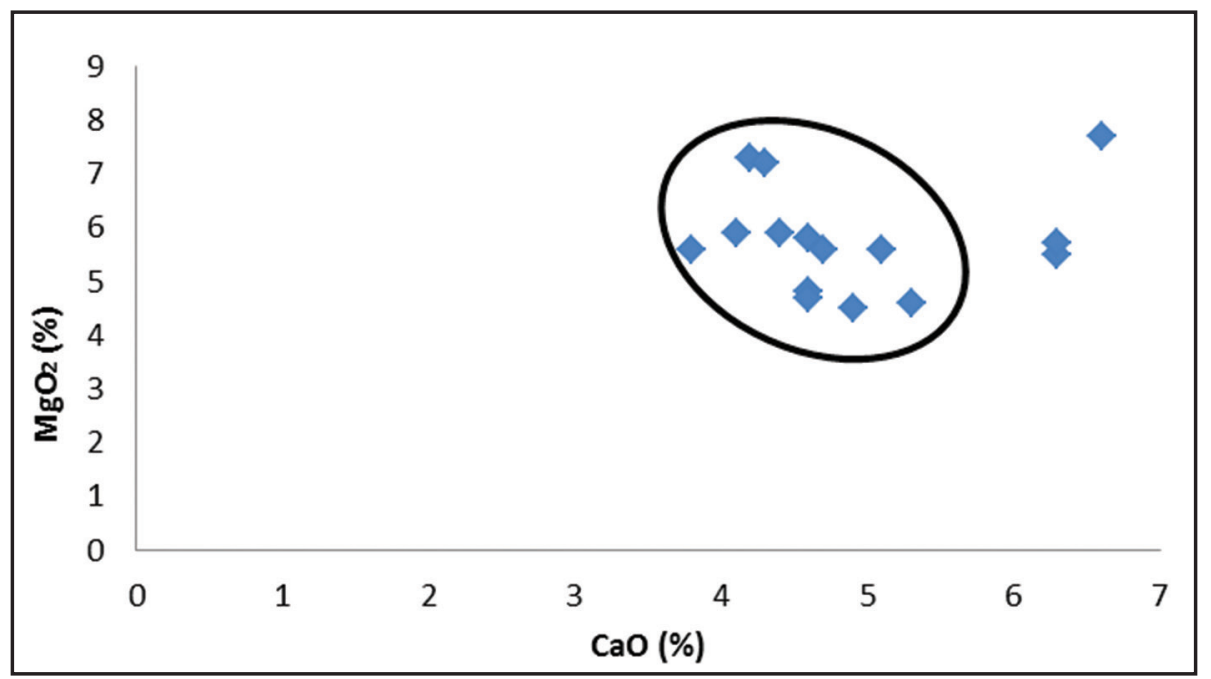

Figure 4. Scatter plot of $\mathrm{CaO}$ versus $\mathrm{MgO}$ percentage of pottery shards from Dahan-e Ghulaman.

Based on these two figures, it can be suggested that most of the pottery shards used the same raw materials and the pottery was locally made.

Hierarchical agglomerative clustering of the $\mathrm{SiO}_{2}$ and $\mathrm{CaO}$ percentage shows that there are two groups: group $\mathrm{A}$, which is considered to be locally produced and has a significant value below 10 , and group $\mathrm{B}$, which is considered to be imported local shards or shards which have certain anomalies (see Figure 5).

Figure 6 shows a hierarchical agglomerative clustering of $\mathrm{CaO}$ and $\mathrm{MgO}$ percentage, which shows there are two component groups. Group A is considered to be locally produced pottery shards with a significant value below 15; group B can be considered imported pottery shards which have higher calcium or magnesium.

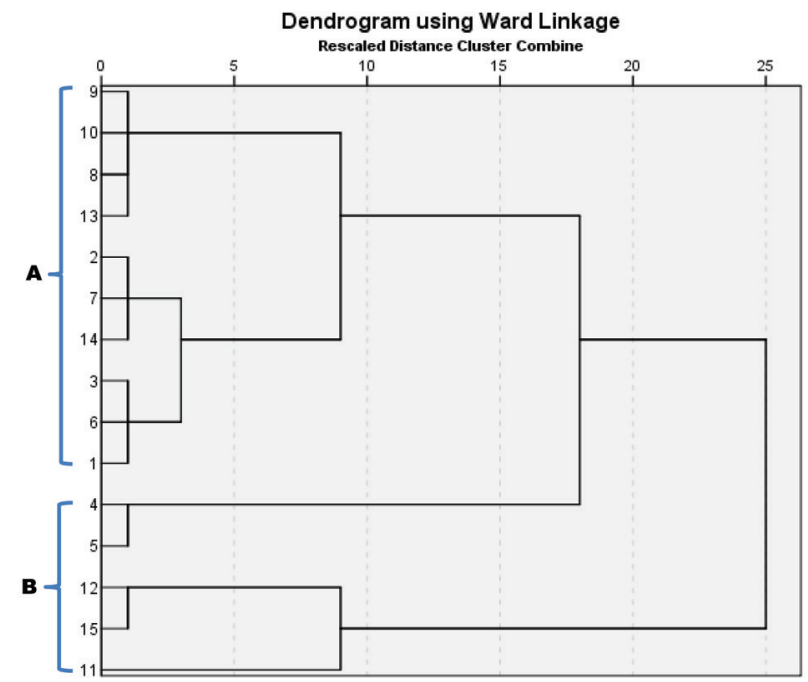

Figure 5. Hierarchical agglomerative clustering of the $\mathrm{SiO} 2$ and $\mathrm{CaO}$ percentage of the pottery shards from Dahan-e Ghulaman.

\section{Conclusion}

The compositional analysis showed that most of the pottery shards taken from the archaeological site in Dahan-e Ghulaman are locally made; based on the assumption of the Provenance Postulate and the Criterion of Abundance. A previous analysis of pottery shards from Sistan showed that since the prehistoric period, there was trade activity in Sistan, and that the activity continued until the Islamic Period. The result of the analysis also showed that the local community from prehistory to the historical period in Sistan was very skilful and knowledgeable in pottery making (see Moradi et al. 2013; Sarhaddi-Dadian et al. 2015b). There are possibilities that five of the samples were imported or are just anomalies; these samples, QH6, QH8, QH26, QH29 and

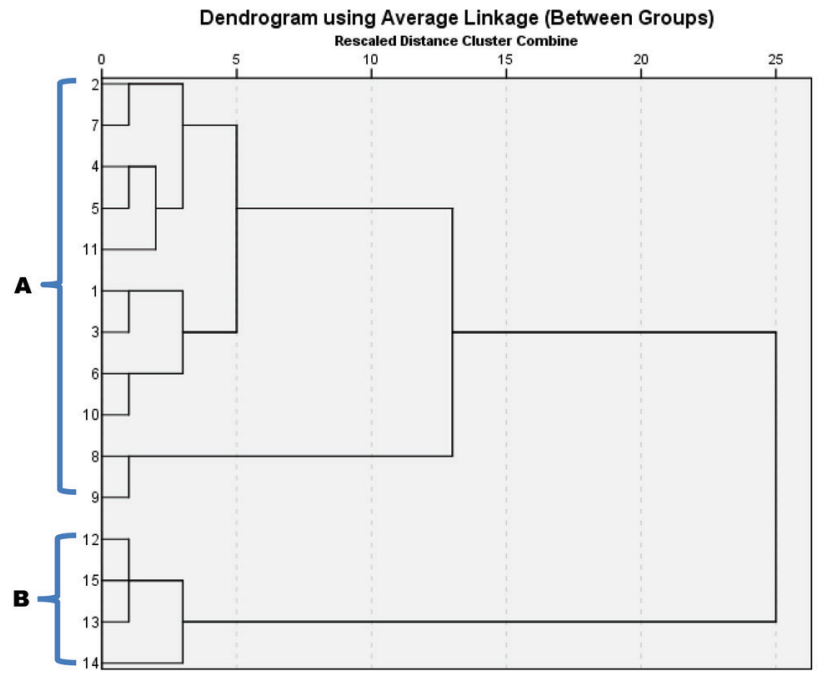

Figure 6. Hierarchical agglomerative clustering of the $\mathrm{CaO}$ and $\mathrm{MgO}$ percentage of the pottery shards from Dahan-e Ghulaman. 
QH38, have higher calcium and magnesium concentrations. It can be suggested that the imported pottery probably came from outside of the Sistan region. The higher content of $\mathrm{P}_{2} \mathrm{O}_{5}$ in the Dahan-e Ghulaman pottery shards shows that some of the pottery was used as food containers.

\section{Acknowledgements}

We express our gratitude to Seyyed Mansour Seyyed Sajjadi, Archaeological Director of International expedition of Shahre Sokhte and Dahan-e Ghulaman for giving us the potsherd sample for analysis. Our especial thanks go to Nooshin Jahantighi for editing the text of the paper.

\section{References}

BISHOP, R. L., RANDS R. L., HOLLY, G. R. 1982: Ceramic Compositional Analysis in Archaeological Perspective. In Schiffer, M. B. (Ed.): Advance in Archaeological Method and Theory. Vol 5. Academic Press, New York.

BUSON, S., VIDALE, M. 1983: The Forming and Finishing Process of the Pear-Shaped Beakers of Shahr-i Sokhta: Analysis of the Relationships between Technological and Morphological Evolution through Experimental Simulation. East and West 33, 31-51.

CALEB, H. 1991: Construction Materials: Type, Uses and Application. The Geological Society of America, New York.

CATTENAT, A., GARDIN, J. C. 1977: Diffusion comparée de quelques genres de poterie caractéristiques de l'époque achéménide sur le Plateau iranien et en Asie Centrale. In: Deshayes, J. (Ed.): Le Plateauiranien et l'Asie centrale des origines à la conquête islamique. Leurs relations à la lumière des documents archéologiques. Editions du CNRS, Paris, $255-249$.

DALES, G. F. 1977: New Excavations at Nad-i Ali (Sorkh Dagh), Afghanistan. Center for South and Southeast Asia Studies, University of California.

GENITO, B. 1990: The Most Frequent Tyoes at Dahan-e Gholaman(Sistan) and Their Spatial Variability. In: South Asian Archaeology. 588-601.

GRISHMAN, R. 1982: L'art de Iran, Medes et Achemenides (Persian edition). Tehran.

LATER, F. Y., GENITO, B. 2010: The Achaemenid Empire as seen from its eastern periphery: The case of Dahan-I Ghulaman in Sistan. In: Proceedings of the $6^{\text {th }}$ International Congress of the Archaeology of the Ancient Near East. 1-77.

MARIANI, L. 1977: Conservation Work on Building 3 at Dahan-e Ghulaman, Sistan. South Asian Archaeology 2, 737-754.

MEHRAFARIN, R. 2016: Alexander the Great in the Realm of Evergetǽs. Mediterranean Archaeology and Archaeometry 16/1, 1-8.
MORADI, H., SARHADDI-DADIAN, H., RAHMAN, N. H. S. N. A. 2014: Development and Decline of the Bampur Valley, Based on the New Archaeological Evidence from Prehistoric Period. Iranian Studies 47/2, 263-287.

MORADI, H., SARHADDI-DADIAN, H., SOLTANI, M., RAHMAN, N. H. S. N. A., CHANG, B. O. 2013b: Study and Typological Comparison of Petroglyphs in the Marzbanik Valley, Baluchestan, Iran. Time and Mind 6/3, 331-349.

MORADI, H., SARHADDI-DADIAN, H., ZULISKANDAR R., RAHMAN, N. H. S. N. A. 2013a: Compositional Analysis of the Pottery Shards of Shahr-I Sokhta, South Eastern Iran. Research Journal of Applied Sciences, Engineering and Technology 6/4, 654-659.

SAJJADDI, S. M. S. 2002: The fourth booklet of Shahre Sokhta: Excavated in Industrial Workshop (Dahane-y Ghulaman). Laporan.

SAJJADDI, S. M. S. 2006: Dahane-y Ghulaman: A City of Achaemenian in Sistan, Second Part. The Journal of Archaeology and History 2, 43-52.

SAJJADI, S. 2007: Wall Painting from Dahaneh-ye Gholaman (Sistan). Ancient Civilizations from Scythia to Siberia 13/1-2, 1-2.

SARHADDI-DADIAN, H., MORAD, H., SOLTANI, M. 2015a: Preliminary Study of Rock Art at Negaran Valley in Baluchistan, Iran. Rock Art Research 32/2, 8-11.

SARHADDI-DADIAN, H. 2013: Archaeology of Sistan, Iran during the Achaemenian Empire (from 550 BC to 331 BC). MS. Doctoral Thesis. Deposited: Library of the National University of Malaysia, Bangi.

SARHADDI-DADIAN, H., ZULISKANDAR, R., NIK HASSAN SHUHAM, N. A. R., MEHRAFARIN, R. 2015b: X-Ray Diffraction and X-Ray Fluorescence Analysis of Pottery Shards from New Archaeological Survey in South Region of Sistan, Mediterranean, Archaeology and Archaeometry, 15/3, 45-56.

SCERRATO, U. 1962: A probable Achaemenid zone in Persian Sistan. In: East and West, 186-197.

SCERRATO, U. 1966: Excavations at Dahan-i Ghulaman (Seistan-Iran) First Preliminary Report (1962-1963). In: East and West, 9-30.

SCERRATO, U. 1977: Evidence of Religious Life at Dahan-e Ghulaman, Sistan. In: South Asian Archaeology, 709-735.

SHARPE, R. N. 2004: Commands of Achaemenid kings. Pazineh, Teheran. SHEIKHAKBARI, S., SARHADDI-DADIAN, H., AMIRHAJLOO, S., DANESHI, A. 2015: Comparative Study of Pottery Industry in Zeh-Klout Historical Period in Roudbar-Kerman with Its Neighbouring Cultures Based on the New Archaeological Evidences. International Journal of Archaeology 3, 22-32.

STRONACH, D. 1978: Pasargadae: a report on the excavations conducted by the British Institute of Persian Studies from 1961 to 1963. Clarendon Press, Oxford.

VOGELSANG, W. 1987: Some Remarks on Eastern Iran in the LateAchaemenid Period. In: Achaemenid History I, Sources, Structure and Synthesis. Leiden, 183-190.

WEIGAND, P. C., HARBOTTLE G., SAYRE. E. V. 1977: Turquoise Sources and Source Analysis: Mesoamerica and the South-Western USA. In: Earle, T. K., Ericson, J. E. (Eds.): Exchange Systems in Prehistory. Academic Press, London, New York, 15-34. 
